\title{
Larval development of nypa palm worm Namalycastis rhodochorde (Polychaeta: Nereididae)
}

\author{
JUNARDI $^{1}$, TJANDRA ANGGRAENI ${ }^{2}$, AHMAD RIDWAN ${ }^{2}$, EDY YOWONO ${ }^{3, \bullet}$ \\ ${ }^{1}$ Department of Biology, Faculty of Mathematics and Natural Sciences, Universitas Tanjungpura. Jl. Prof. Dr. H. Hadari Nawawi, Pontianak 78124, West \\ Kalimantan, Indonesia. Tel./fax.: +62-561-577963, `email: edyyuwono@gmail.com, junardi@ fmipa.untan.ac.id \\ ${ }^{2}$ School of Life Science and Technology, Institut Teknologi Bandung. Jl. Ganesha 10, Bandung 40132, West Java, Indonesia \\ ${ }^{3}$ Graduate School of Biology, Univesitas Nasional. Jl. R.M. Harsono, Ragunan, Jakarta Selatan 14430, Jakarta, Indonesia
}

Manuscript received: 2 August 2020. Revision accepted: 30 October 2020

\begin{abstract}
Junardi, Anggraeni T, Ridwan A, Yowono E. 2020. Larval development of nypa palm worm Namalycastis rhodochorde (Polychaeta: Nereididae). Nusantara Bioscience 12: 148-153. Namalycastis intensive culture is still facing problems in mass production due to limited information on reproduction, especially in fertilization and production of larvae. The present research was designated to find out optimum salinity for fertilization and the production of nypa palm worm larvae (Namalycastis rhodochorde). Gamete samples were collected using a capillary glass tube inserted into ventro-lateral part of a body segment of a mature worm. Artificial fertilization was done by mixing the sperms and oocytes in a fertilization dish containing sterilized seawater as the medium. The larval development was observed until the benthic phase larvae (3-setigers). Fertilization was performed in medium salinity of 7-21\%o and water temperature of $25-29^{\circ} \mathrm{C}$. The cleavage and larva stage occurred respectively within 28.20 to 58.67 minutes and within 72 to 80 hours after fertilization. The fertilization and larval development of $N$. rhodochorde were highly influenced by the medium salinity and temperature.
\end{abstract}

Keywords: Fertilization, larval development, Namalycastis rhodochorde, Polychaeta, salinity

\section{INTRODUCTION}

The supply of polychaete worm has been suggested to alleviate the problem of feed for shrimp broodstock in the aquaculture industry. The worm contains nutrients essential to promote successful reproductive performance by improving the number of eggs per spawning, increased egg viability, and larval survival in shrimp broodstock (Babu 2013). The nutrient possessed by polychaete comprises essential amino acids, unsaturated fatty acids, and cholesterol, as well as chemoattractant properties (Chimsung 2014; Phoonsamran et al. 2017). The nereid polychaetes, for example, Nereis (Hediste) diversicolor and D. pinnaticirris, are rich in unsaturated fatty acids such as arachidonic, eicosapentaenoic acids, docosapentaenoic and docosahexaenoic acids and has a balanced essential amino acid (Wang et al. 2019; Wang et al. 2020). Other nereids such as P. cultrifera (Rettob et al. 2013) and D. pinnaticirris (Wibowo et al. 2020) contain essential amino acids dominated by chemoattractant for shrimp. In addition, Perinereis sp. possesses prostaglandin $\mathrm{E}_{2}\left(\mathrm{PGE}_{2}\right)$ and progesterone (P4) and 17-alpha hydroxyprogesterone (17 $\alpha$-OHP4), which have an effect on vitellogenesis and maturity of shrimp gametes (Meunpol 2010). For that reason, the polychaete worm has been intensively used for marine shrimp broodstock maturation diets.

Nereidid polychaetes often occur as major components of the macrobenthic fauna in estuaries (Sato 2017; Ibrahim et al. 2019). Nypa palm worm (Namalycastis rhodochorde) is one of the Nereidid Polychaeta species that has long been used as fishing bait for fish and shrimp in West
Kalimantan, Indonesia (Junardi et al. 2014). The worm and other polychaetes, including Arenicolidae, Glyceridae, Nephtyidae, and Eunicidae, are harvested from its natural habitat for fishing bait (Carvalho et al. 2013; Saito et al. 2014). The massive collection of polychaete worm from its habitat for commercial purposes is considered nonsustainable for the environment, as it contributes to the depletion of natural resources (Pires et al. 2012). Unfortunately, scientific knowledge such as reproduction and larval development of $N$. rhodochorde, which could be applied in the worm mass culture and the maintenance of natural stock sustainability, is not considered available. Development and reproduction of N. abiuma were already studied (Junardi et al. 2013). Meanwhile, the study on reproduction, especially early embryonic development of $N$. rhodochorde has not been undertaken.

Temperature and salinity are key factors affecting the physiological and ecological responses of organisms, including polychaetes inhabiting estuaries and brackish waters (Dańko et al. 2020). For instance, uninterrupted embryonic and larval development of the polychaete worms $H$. carunculata does not occur at $22^{\circ} \mathrm{C}$ meanwhile, normal larval development takes place at $27^{\circ} \mathrm{C}$ (Toso et al. 2020). The nypa palm worm, $N$. rhodochorde, which inhabit estuary, encounters a highly dynamic physicochemical change in time and space scales. The worm ought to have an adaptive capacity to live in a wide range of temperature and salinity.

Epitokous phase of polychaete reproduction has become a reference for the study of fertilization, larval development, and the factors that influence it. However, 
some species, such as $N$. glandicincta (Ibrahim et al. 2019), $N$. abiuma (Junardi et al. 2014), and D. pinnaticirris (Wibowo et al. 2020) do not have such epitokous phase that reproduction time cannot be predicted. The characteristics of larval development cannot readily be determined. Larval development and fertilization studies in polychaete have been done since the 1960s, and recent studies of larval development of Mooreonuphis stigmatis (Budaeva and Fauchald 2010), N. abiuma (Junardi et al. 2013), and $N$. diversicolor (Wang et al. 2020) were carried out. Since 1980s further study on polychaete embryonic development and artificial fertilization has been developed for providing scientific information applied in commercial polychaete aquaculture (Olive 1999). The present study is designated to find out the optimum salinity for fertilization and larval development of nypa palm worm, $N$. rhodochorde larvae.

\section{MATERIALS AND METHODS}

\section{Collection of adult specimens}

Nypa palm worms, $N$. rhodochorde were collected from the mangrove area of Kapuas estuarine in West Kalimantan, Indonesia on May-July 2012 at low spring tides. The worm was transported to the Zoology Laboratory, Tanjungpura University, Pontianak, West Kalimantan using a container filled with sediment taken from its natural habitat. As soon as its arrived at the laboratory (about 30 minutes), the specimen was then removed from the container by handpicking. The visual sorting was done to selectively seize mature worms from immature individuals. Selected mature worms were then placed in a separate container. Mature individuals were distinguished from the immatures based on body coloration. Female mature individuals showed reddish body color, while mature males showed greenish body color.

\section{Collection of gametes}

Gametes from each individual were drawn by inserting a capillary glass tube into the ventrolateral part of body segments, and the fresh gamete sample was observed under a light microscope. The matured egg was determined by measuring its diameter and identifying the appearance of lipid droplets in the ooplasm. Egg diameter was measured by eyepiece micrometer, and it is used as an indicator of fertilization success. The maturing egg diameter, in which lipid droplets have already undoubtedly appeared in ooplasm, ranged between $120-130 \mu \mathrm{m}$. We used sperm samples taken from males with pale greenish ventral body color as an indication of maturity. Maturing eggs and spermatozoa with a $2: 1$ ratio, respectively, were then mixed in a dish containing a fertilization medium of sterilized filtered seawater.

\section{Fertilization experiments}

Fertilization was conducted in the laboratory within the medium of sterilized filtered seawater. Initially, the experiment was carried out in a series of salinity ranging from $1 \%$ to $33 \%$, i.e., $1-3 \%$ until $31-33 \%$ at room temperature. The fertilization rate was calculated based on the percentage of the successfully fertilized egg to the total number of eggs in a sterilized glass petri dish $(6 \mathrm{~cm}$ in diameter, eggs number in each dish $=30$ ). The highest number of the fertilized egg and larval development among fertilization dishes containing medium with different salinities were ascertained and applied to determine the optimum salinity for artificial fertilization and growing the larvae. The required water salinity was obtained by mixing seawater and distilled water. Medium salinity was measured with a hand refractometer for salinity (Atago ATC-S/Mill-E, Japan). Optimum salinity was determined by designating the different salinity of seawater in the experimental dishes in which successful fertilization, cleavage, and larval development were found.

The fertilization process was observed under the Nikon Eclipse TE300 inverted microscope equipped with Nikon DXM 1200F camera. Successful fertilization was determined by the formation of the fertilization membrane and the initiation of egg cell division. The egg was then observed every 5 to 10 minutes. Unfertilized eggs were counted and then removed from the fertilization medium. The process of development comprises the cleavage stages of $2,4,8,16$, and 32 cells until the 3 -setiger larval stage. Larval morphology and development were observed and described at each stage of development. Larval morphological characteristic refers to other larvae of Nereididae (Rouse 2000), Hediste (Sato 1999) and Namanereis littoralis (Ezhova 2011). Descriptive analysis was used to compare based on a photographic series of their development.

\section{RESULTS AND DISCUSSION}

\section{Results \\ Description of larval development}

Maturing eggs are indicated by the accumulation of lipid droplets in the center of ooplasm (Figure 1A), meanwhile fertilized eggs were indicated by perivitelline vesicle and gelatinous, adhesive outer membrane (Figure 1B). The fertilized eggs are surrounded by a fertilization membrane. An appearance of all developmental stages of nypa palm worm is presented in Figure 2.

Fertilization was accomplished during minutes 28.20 to $58.67(n=20)$ on average (Table 1$)$. The characteristics of cell division were described by the spiral cleavage, holoblastic, meridional, and unequal (Figure 2A-D). The first cleavage occurred between 10 to 100 minutes after fertilization was initiated by the formation of unequal blastomeres.

Table 1. The cleavage of Namalycastis rhodochorde in a 7-21\%o salinity range

\begin{tabular}{ccc}
\hline $\begin{array}{c}\text { Salinity } \\
\text { (\%o) }\end{array}$ & $\begin{array}{c}\text { Average time } \\
\text { (minutes) }\end{array}$ & $\begin{array}{c}\text { Number of experiments } \\
\text { (n) }\end{array}$ \\
\hline $7-9$ & 58.67 & 3 \\
$10-12$ & 28.20 & 5 \\
$13-15$ & 37.40 & 5 \\
$16-18$ & 51.00 & 4 \\
$19-21$ & 35.67 & 3 \\
\hline
\end{tabular}




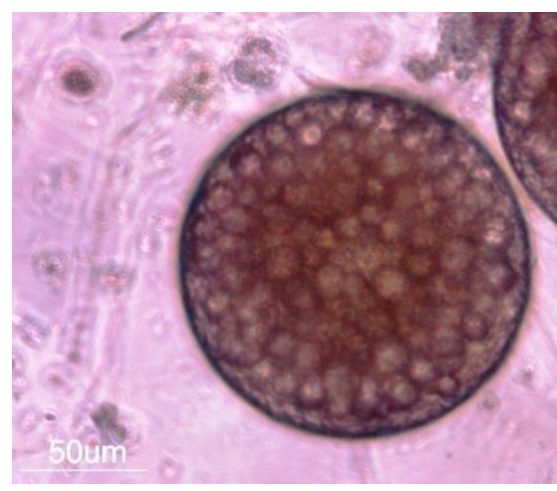

A

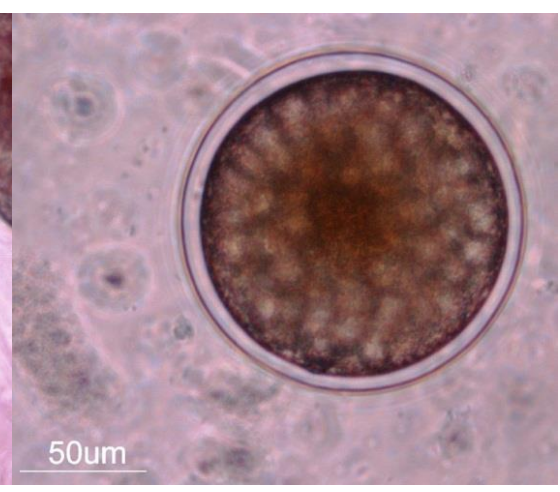

B

Figure 1. Eggs of Namalycastis rhodochorde. A. Unfertilized; B. Fertilized (zygote)
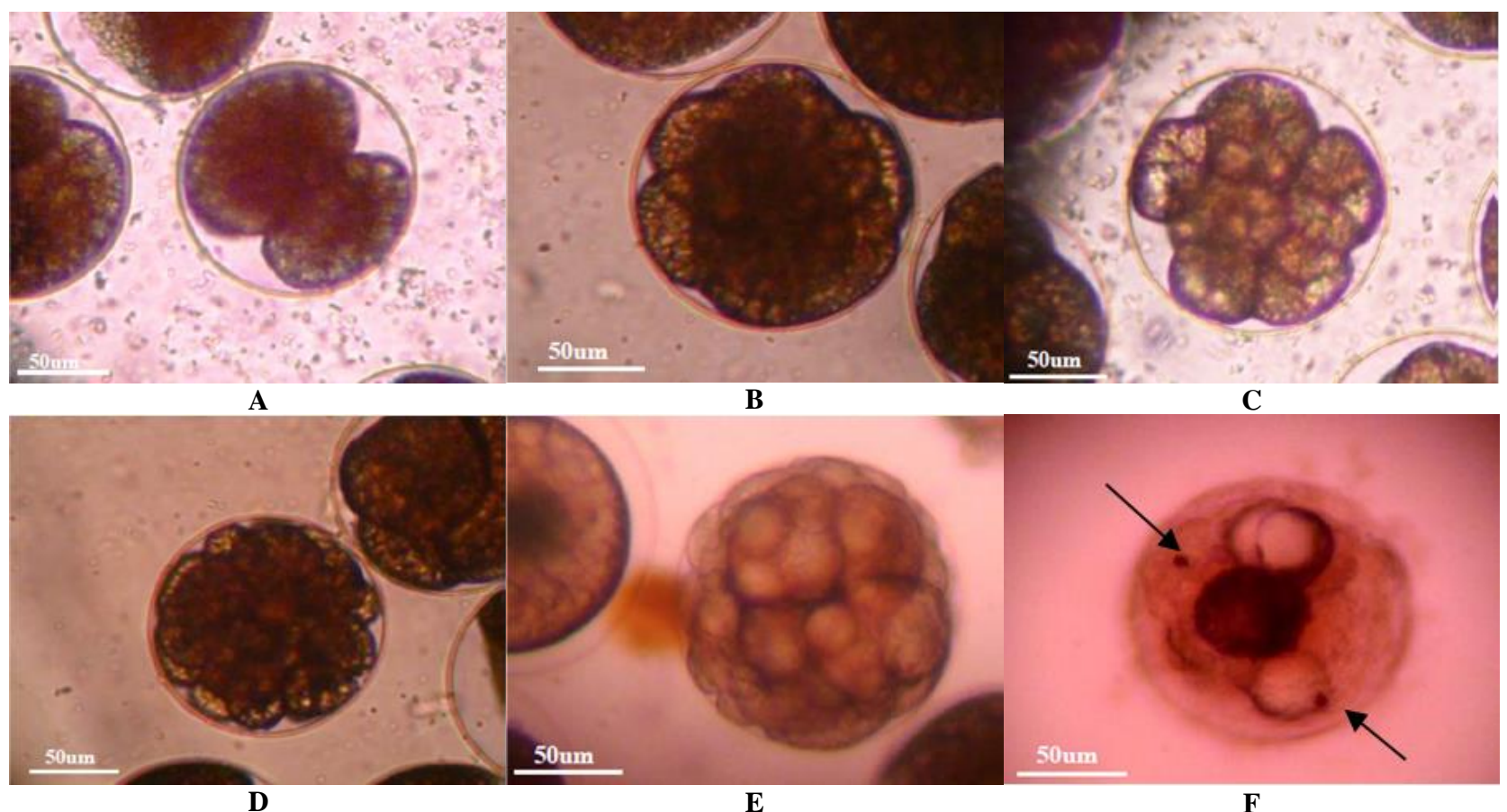

B

C

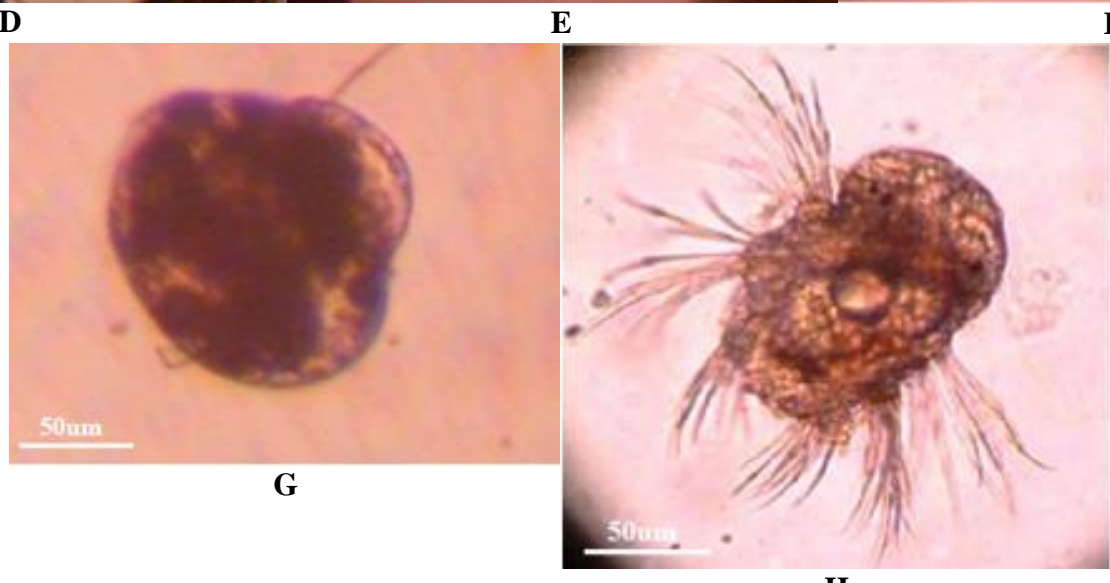

$\mathbf{H}$

Figure 2. Stages of larval development of Namalycastis rhodochorde. A. 2-cell division (36 minutes); B. 4-cell division (42 minutes); C. 8-cell division (53 minutes); D. 16-cell division (120 minutes); E. 32-cell division (150 minutes, rotating larvae); F. trochophore larvae with two eyes (240 minutes, free-swimming larvae, black arrows indicated eyes); G. metatrochophore (22 hours); H. 3 -setiger early nectochaeta ( 3 days) 
Early trochophore larvae exhibited slow rotation driven by multi-ciliated equatorial prototroch (Figure 2E) and followed by the formation of two eyes (Figure 2F). The next stage was late trochophore (Figure 2G) and metatrochophore indicated by the development of chaetae and chaetigerous segment. The larvae were then supplemented by the development of chetigerous parapodia (chetiger) and antenna at the prostomium part of the larval body. Segmented larvae formation of the three first segments (3-setiger) or early nectochaeta (Figure $2 \mathrm{H}$ ) was formed within three days after fertilization. The final stage of larval development is called nectochaeta, which takes six days. The morphological characteristic of this final stage is the formation of a pair of tentacular cirri and anal cirri in the part of the body.

\section{Fertilization experiments}

Free-swimming larvae have a high mortality rate when the salinity of the culture media is lower than $7 \%$ or higher than 21\%o (Figure 3). Optimum salinity for fertilization and larval development was ranged between 10-21\%o. Based on this result, we conclude that larval survival is strongly influenced by water salinity. Survival of embryo until 3chetiger larvae are only found in the salinity range of 10 $18 \%$ (Figure 4). The highest survival was found in salinity $10-12 \%$ as much as $18 \%$, followed by $13-15 \%$ ( $8 \%$ ) and salinity $16-18 \%$ (6\%).

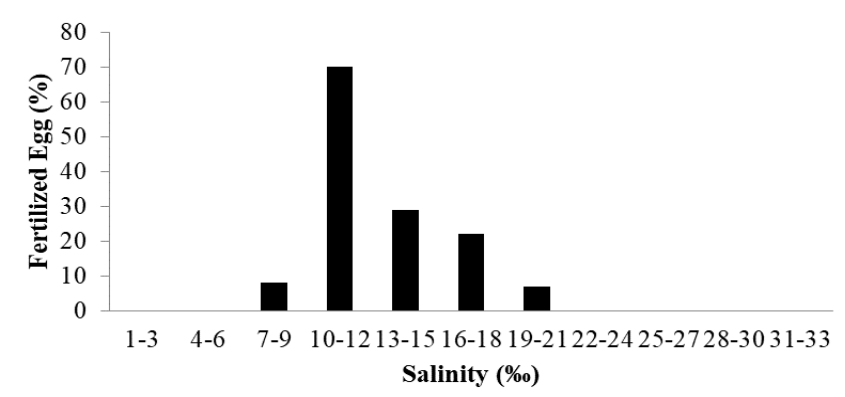

Figure 3. Percentage of eggs of Namalycastis rhodohorde fertilized with different salinity

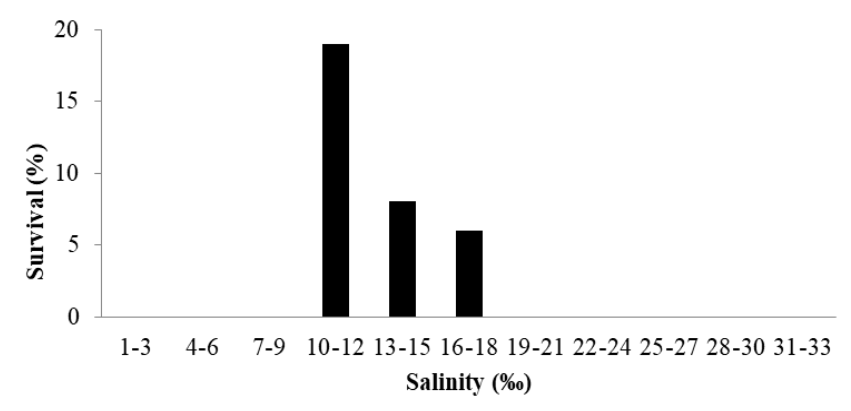

Figure 4. Percentage of 3-chetigers larvae of Namalycastis rhodochorde which were surviving on different salinity after three days

\section{Discussion}

In general, maturity of Nereid worm such as Perinereis cultrifera (Rettob et al. 2013), N. glandicincta, and N. wilsonchani (Lee and Glasby 2015; Ibrahim et al. 2019) was characterized by swarming epitoke and with or without changes of body color. Unlike other nereidid species such as Neanthes glandicincta, Ceratonereis (Composetia) burmensis (Lee and Glasby 2015), and Neanthes glandicincta (Ibrahim et al. 2019), the nypa palm worm does not form modified parapodia, chaeta, and eyes for spawning processes in the water (Junardi et al. 2014). Nypa palm worm maturity characteristic was much the same as Nereis diversicolor (Wang et al. 2020) and D. aestuarina (Jayachandran et al. 2015). The nypa palm worm maturity is characterized only by changes in body color and nonswarming epitoke. Matured male individuals were characterized by the changing of body color from pink to dark red with greenish, while the matured female individuals exhibited dark-red on the side part of the body (Junardi et al. 2014) while the females of mature $N$. diversicolor showed a yellowish, dark green color (Wang et al. 2020). Similar to Nereis sp. (Sahu et al. 2017) and the mature oocytes of $N$. rhodochorde were characterized by a spherical shape with a diameter ranged between 120$130 \mu \mathrm{m}$. The oocyte shape of $N$. rhodochorde is different from that of $N$. littoralis egg, which is oval (Ezhova 2011). The size of matured eggs of $N$. rhodochorde is smaller than that of P. cultrifera (Rettob et al. 2013) and Nereis sp. (Sahu et al. 2017) that reach $240 \mu \mathrm{m}$ and $325.82 \mu \mathrm{m}$ in diameter, respectively.

Fertilized egg showed lipid droplets migration to the peripheral part of the egg. This characteristic is also found in other Nereidid species i.e., P. dumerilii (Fischer 2010). The cleavage of $N$. rhodochorde is also similar to P.dumerilii (only Nereididae) characterized by a series of asymmetric cell divisions (ACDs) that generates cells of different size and defined position within the early embryo (Nakama et al. 2017). After the 32-cell division, the next stage is a stereoblastula. The Prototrochopore indicated by slowly rotating, and then the early stage of trochophore larvae indicated by actively swimming in the water column and lipid droplets still exist in these stages. Lechitotropic larvae are short-period growing larvae with the yolk as a food source for metamorphosis. However, the characteristics of the nypa palm worm's larvae could be very different at the subfamily level. For example, latestage $N$. littoralis larvae are coated inside a capsule rather than free-swimming larvae (Ezhova 2011).

The trochophore larvae of $N$. rhodochorde are also characterized by the enlargement of its diameter from 140 $\mu \mathrm{m}$ into $200 \mu \mathrm{m}$ with body surrounding cilia (equatorial cilia) and two-eye development. Free-swimming larvae emerged on the second day after fertilization; it was gradually turned into the oval and ciliated body at the latero-dorsalis part. These free-swimming larvae have a high mortality rate when the culture media's salinity is lower than $7 \%$ or higher than $21 \%$. The low survival of the polychaete most probably is affected by low salinity 
(Leung et al. 2013). Based on this result, we conclude that larval survival is strongly influenced by water salinity.

Many polychaetes species of family nereidid inhabit estuary ecosystems (Pederson et al. 2010; Saito et al. 2014; Linden et al. 2017) subjected to a high degree of variability in their environmental conditions, especially salinity variation due to freshwater and seawater inputs (Hernández-Alcántara et al. 2014). Such dynamic environmental conditions were presenting a number of problems for externally fertilizing species, and consequently, their fertilization success might occur in an optimum range of medium salinity. An extreme salinity level brings about osmotic stress associated with cell shrinkage or lysis. The mechanism for coping with osmotic stress is volume regulation (Hoffmann and Pedersen 2011) and such physiological response that facilitates the worm to tolerate a wide range of medium salinity. It has been reported that mature oocytes fertilization in Nereidid might occur in a wide range of medium salinity, but Dendronereis aestuarina fertilization occurs in a purely freshwater environment of Periyar River on the southwest coast of India (Jayachandran et al. 2015). In the present study, we found that optimum salinity for fertilization was ranged between $7-21 \%$ and $10-11 \%$ for larvae survival. It seems that the reproduction characteristic of $N$. rhodochorde is well fitted to fluctuating salinity in the estuarine environment. Similar to most estuarine polychaetes (Hernández-Alcántara et al. 2014), the nypa palm worm seems to be well adapted to salinity variations in its habitat. The range of salinity was also found to be convenient for nypa palm worm larval development. The optimum range of salinity was also found similar to that of subfamily level, N. littoralis (6-21\%o) (Ezhova 2011). On the other hand, at family level, such as Hediste diadroma could adapt to higher salinity of $27.5-30 \%$, which is usually unfavorable for fertilization of other Nereidid species (Junardi et al. 2014).

The fertilization and larval development of $N$. rhodochorde is highly influenced by water salinity. In this study, salinity for fertilization and larval development before 3-chetigers ranged between 7-21\%. Meanwhile, the survival of $P$. rullieri, kept in salinity of $10 \%$ in firstmonth experiment, was 60\% (Prevedelli and Vandini 1997). This salinity is lower than that of Hediste japonica larvae well developed in the range of 10-30\%o (Tosuji and Sato 2006) and salinity for development of $N$. virens in 22\%o (Ushakova and Sarantchova 2004). The difference in salinity depends on the species and locality for environmental adaptation. The salinity range for larval development in this study can be used for further studies on the favorable salinity for survival rate of the larvae.

Temperature is an important environmental factor affecting estuarine organisms' physiological responses (Dańko et al. 2020). The present study demonstrates that the water temperature of $25-29^{\circ} \mathrm{C}$ is favorable for nypa palm worm fertilization and larval development. This confirms previous findings that polychaete larval development does not occur at $22^{\circ} \mathrm{C}$, but normal larval development occurs at $27^{\circ} \mathrm{C}$ (Toso et al. 2020). In fact, the temperature range in tropical estuaries is always reasonably favorable because normally almost similar all year round, while in the temperate zone, the temperature drops during autumn and winter at the level unfavorable for reproduction and development. However, it is interesting to study the impact of the rising temperature due to global warming on Polychaetes reproduction and development from the tropical zone in the future.

\section{ACKNOWLEDGEMENTS}

The authors wish to thank the Ministry of Research, Technology, and Higher Education of Indonesia for the dissertation research grant and Head of Zoology Laboratory Tanjungpura University, Pontianak, Indonesia for supporting laboratory facilities.

\section{REFERENCES}

Babu KR. 2013. Improved maturation of wild and pond-reared black tiger shrimp Penaeus monodon (Fabricius) using different combinations of live and wet feeds. Asian J Exp Sci 27 (2): 37-42.

Budaeva N, Fauchald K. 2010. Larval development of Mooreonuphis stigmatis (Treadwell, 1922) (Polychaeta: Onuphidae) from the northeast Pacific. Mar Biol Res 6 (1): 6-24. DOI: 10.1080/17451000902932977

Carvalho AN, Vaz ASL, Sérgio TIB, Santos PJT. 2013. Sustainability of bait fishing harvesting in estuarine ecosystems-Case study in the Local Natural Reserve of Douro Estuary, Portugal. J Integr Coast Zone Manag 13 (2): 157-168.

Chimsung N. 2014. Maturation diets for black tiger shrimp (Penaeus monodon) broodstock: a review. Songklanarin J Sci Technol 36 (3): 265-273.

Dańko A, Schaible R, Dańko MJ. 2020. Salinity effects on survival and reproduction of hydrozoan Eleutheria dichotoma. Estuar Coast 43:360-374. DOI: $10.1007 / \mathrm{s} 12237-019-00675-2$

Ezhova EE. 2011. Spawning and early ontogenesis of the littoral polychaete Namanereis littoralis (Grube, 1876) (Nereididae, Namanereidinae). Russ J Dev Biol 42 (160): 159-166.

Fischer AH. 2010. The normal development of Platynereis dumerilii (Nereididae, Annelida). Front Zool 7: 1-39. DOI: 10.1186/1742-99947-31.

Hernández-Alcántara P, Cortés-Solano JD, Medina-Cantú NM, AvilésDíaz AL, Solís-Weiss V. 2014. Polychaete diversity in the estuarine habitats of Términos Lagoon, southern Gulf of Mexico. Mem Mus Vic 71: 97-107. DOI: 10.24199/j.mmv.2014.71.10

Hoffmann EK, Pedersen SF. 2011. Cell volume homeostatic mechanisms: Effectors and signalling pathways. Acta Physiol 202 (3): 465-485. DOI: $10.1111 /$ j.1748-1716.2010.02190.x

Ibrahim NF, Ibrahim YS, Sato M. 2019. New record of an estuarine polychaete, Neanthes glandicincta (Annelida, Nereididae) on the eastern coast of Peninsular Malaysia. Zookeys 831: 81-94. DOI: 10.3897/zookeys.831.28588

Jayachandran PR, Prabhakaran MP, Asha CV, Vijay A, Nandan SB. 2015. First report on mass reproductive swarming of a polychaete worm, Dendronereis aestuarina (Annelida, Nereididae) Southern 1921 from a freshwater environment in the southwest coast of India. Int J Mar Sci 5 (3): 1-7. DOI: 10.5376/ijms.2015.05.0003

Junardi, Anggraeni T, Ridwan A, Yuwono E. 2014. The maturity of nypa palm worm Namalycastis rhodochorde (Polychaeta: Nereididae). In: Djamal M, Vierdayanti K, Alamsyah IM, Mukti RR, Indrasari W, Islahuddin (eds). Proceeding of 4th International Conference on Mathematics and Natural Sciences (ICMNS 2012): Science for Health, Food and Sustainable Energy, Institut Teknologi Bandung, Bandung, 8-9 November 2012.

Junardi, Anggraeni T, Ridwan A, Yuwono E. 2013. Early ontogenesis of small nypa palm worm Namalycastis abiuma (Polychaeta: Nereididae). In: Prabowo RE, Maharning AR, Ardli ER, Pramono H, Wijayanti GR, Sastranegara MH, Sistina Y (eds). Proceeding of 
International symposium on Indonesian Biodiversity. Jenderal Soedirman University, Purwokerto, 31 October - 1 November 2013.

Lee YL, Glasby CJ 2015. A new cryptic species of Neanthes (Annelida: Phyllodocida: Nereididae) from Singapore confused with Neanthes glandicincta Southern, 1921 and Ceratonereis (Composetia) burmensis (Monro, 1937). Raffles Bull Zool Supp 31: 75-95.

Leung YS, Shin PKS, Qiu JW, Chiu JMY, Thiyagarajan V, Cheung SG. 2013. Physiological and behavioural responses of different life stages of a serpulid polychaete to hypoxia. Mar Ecol-Prog Ser 477: 135-145. DOI: $10.3354 /$ meps 10175 .

Linden P, Marchini A, Smith CJ, Dolbeth M, Simone LRL, Marques JC, Molozzi J, Medeiros CR, Patrício J. 2017. Functional changes in polychaete and mollusc communities in two tropical estuaries. Estuar Coast Shelf Sci 187: 62-73. DOI: 10.1016/j.ecss.2016.12.019

Meunpol O. 2010. Detection of prostaglandin E2 in polychaete Perinereis sp. and its Effect on Penaeus monodon oocyte Development in vitro. Fish Sci 76: 281-286.

Nakama AB, Chou H-C, Schneider SQ. 2017. The asymmetric cell division machinery in the spiral-cleaving egg and embryo of the marine annelid Platynereis dumerilii. BMC Dev Biol 17: 16. DOI 10.1186/s12861-017-0158-9

Olive PJ. 1999. Polychaete aquaculture and polychaete science: Mutual synergism. Hydrobiologia 402: 175-183.

Pederson TM, Almeda R, Fotel FL, Jakobsen HH, Mariani P, Hansen BW. 2010. Larval growth in the dominant polychaete Polydora ciliata is food-limited in a eutrophic Danish estuary (Isefjord). Mar Ecol-Prog Ser 407: 99-110. DOI: 10.3354/meps08563

Phoonsamran K, Direkbusarakom S, Chotipuntu P, Hirono I, Unajak S, Summpunn P, Wuthisuthimethavee S. 2017. Identification and expression of vitellogenin gene in Polychaetes (Perinereis sp.). J Fish Environ 41 (1): 1-10.

Pires A, Gentil F, Quintino V, Rodrigues AM. 2012. Reproductive biology of Diopatra neapolitana (Annelida, Onuphidae), an exploited natural resource in Ria de Aveiro (Northwestern Portugal). Mar Ecol 33: 56-65. DOI: $10.1111 / \mathrm{j} .1439-0485.2011 .00463 . x$

Prevedelli D, Vandini RZ. 1997. Survival and growth rate of Perinereis rullieri (Polychaeta, Nereididae) under different salinities and diets. Italian J Zool 64: 135-139. DOI: 10.1080/11250009709356186

Rettob M, Arfiat D, Hakim L, Lumingas L. 2013. Reproduction aspects of marine worms Perinereis cultrifera (Grube, 1840) in Langgur Waters, Lesser Kei Islands, Southeast Maluku Regency, Indonesia. Int J Basic Appl Sci 13 (1): 31-35.

Rouse G. 2000. Polychaetes have evolved feeding larvae numerous time. Bull Mar Sci 67 (1): 391-409.
Sahu SK, Singh R, Murugesan V, Muthuvelu S, Kathiresan K. 2017. Biochemical studies on the live feed polychaete, Nereis sp. in relation to maturity stage. Indian J Geo-Mar Sci 46 (3): 591-596.

Sato M. 1999. Divergence of reproductive and developmental characteristics in Hediste (Polychaeta: Nereididae). In: Dorresteijn AWC, Westheide W (eds). Reproductive Strategies and Developmental Patterns in Annelids. Springer, Dordrecht.

Sato M. 2017. Nereididae (Annelida) in Japan, with special reference to life-history differentiation among estuarine species. In: Motokawa M, Kajihara H (eds). Species Diversity of Animals in Japan. Springer Japan, Tokyo.

Saito H, Kawai K, Umino T, Imabayashi H. 2014. Fishing bait worm supplies in Japan in relation to their physiological traits. Mem Mus Vic 71: 279-287. DOI: 10.24199/j.mmv.2014.71.21

Toso A, Boulamail S, Lago N, Pierri C, Piraino S, Giangrande A. 2020. First description of early developmental stages of the native invasive fireworm Hermodice carunculata (Annelida, Amphinomidae): a cue to the warming of the Mediterranean Sea. Mediterr Mar Sci 21 (2): 442-447. DOI: $10.12681 / \mathrm{mms} .22043$

Tosuji H, Sato M. 2006. Salinity Favorable for early development and gamete compatibility in two sympatric estuarine species of the genus Hediste (Polychaeta: Nereididae) in the Ariake Sea, Japan. Mar Biol 148: 529-539.

Ushakova OO, Sarantchova OL. 2004. The influence of salinity on fertilization and larval development of Nereis virens (Polychaeta, Nereidae) from the White Sea. J Exp Mar Biol Ecol 301 (2): 129-139. DOI: $10.1016 /$ j.jembe.2003.09.025

Wang H, Seekamp I, Malzahn A, Hagemann A, Carvajal AK, Slizyte R, Standal IB, Handa A, Reitan KI. 2019. Growth and nutritional composition of the polychaete Hediste diversicolor (OF Müller, 1776) cultivated on waste from land-based salmon smolt aquaculture. Aquaculture 502: 232-241. DOI: 0.1016/j.aquaculture.2018.12.047

Wang H, Hagemann A, Reitan KI, Handå A, Uhre M, Malzahn AM. 2020. Embryonic and larval development in the semelparous Nereid polychaete Hediste diversicolor (OF Müller, 1776) in Norway: Challenges and perspectives. Aquac Res 00:1-17. DOI: 10.1111/are. 14756

Wibowo ES, Yuwono E, Sukardi P, Siregar AS, 2020. Survival rate, growth, and chemical content of Dendronereis pinnaticirris (Polychaeta, Nereidae) in maintenance with different feeds and substrates. Indones J Mar Sci 25 (2): 75-84. DOI: 10.14710/ik.ijms.25.2.75-84. 